Representations of a high-quality system of undergraduate education in English higher education policy documents

Paul Ashwin

*, Andrea Abbasb and Monica McLean

Department of Educational Research, County South, Lancaster University, Lancaster, LA1 4YD, UK;

Centre for Educational Research and Development, University of Lincoln,

Brayford Pool, Lincoln, LN6 7TS, UK;

School of Education, Dearing Building, University

of Nottingham, Jubilee Campus, Nottingham, NG8 1BB, UK

This article examines the ways in which a high-quality system of undergraduate education is represented in recent policy documents from a range of actors interested in higher education. Drawing on Basil Bernstein's ideas, the authors conceptualise the policy documents as reflecting a struggle over competing views of quality that are expressed through pedagogic discourses. They identify two pedagogic discourses: a dominant market-oriented generic discourse and an alternative discourse that focuses on transformation. They argue that the marketoriented generic discourse is dominant because it is more coherent and more consistently presented than the alternative discourse, which is much more fractured. In conclusion, they argue that refocusing the alternative discourse of quality around students' relations to academic knowledge may offer a way in which to bring the different actors from the higher education field together in order to form a stronger, more cohesive voice.

Keywords: higher education policy; pedagogic discourse; Quality; Basil Bernstein; undergraduate education

Introduction: markets and quality

Recent changes to the funding of undergraduate education in England have been argued to fundamentally challenge the historic role of universities as autonomous and critical institutions (for example, Doherty 2011; Holmwood 2011; Molesworth, Scullion, and Nixon 2011; Collini 2012). Changes in funding are seen as part of a wider set of changes that have for some time been argued to be leading to the 'marketisation' of undergraduate higher education in which universities have increasingly had to compete for students, who are positioned as consumers of higher education (see Dill 1997, 2007; Meek and Wood 1997; Williams 1997; Morley 2003; Bok 2006; Brown 2006, 2011a; McCulloch 2009; Cuthbert 2010; Barrett 2011; Dodds 2011; Watson 2011). In the English context, the marketisation of undergraduate education has intensified with rises in student numbers and the introduction and increases in the fees that students pay for their tuition. This has led to a more intense focus on the 'quality' of higher education, as students as customers are seen to require reliable information about the quality of the product they are purchasing, and the competition for these students is seen as improving the quality of the product (Green 1994; Vidovich 2002; Morley 
2003; Brown 2006, 2011a, b; Blackmur 2007; Blackmore 2009). Whilst marketisation has led to an increased focus on the quality of undergraduate education, it does not, as Young (2008) notes in relation to knowledge, define the meaning of quality because markets are reliant on definitions from elsewhere. This means that it is important to chart and understand the definitions of quality that are used both implicitly and explicitly in policy documents and the ways in which particular definitions appear to dominate. This matters because what comes to be counted as a quality in relation to undergraduate education helps to shape the basis on which universities are judged and evaluated, and thereby frames their role in society. The literature on quality in higher education has indicated a struggle between a marketised, consumerised definition of the quality of higher education being about fitness for purpose and value for money and definitions of quality that are based on the transformation of students (for example, see Harvey and Green 1993; Green 1994; Bowden and Marton 1998; Shields 1999; Morley 2003; Houston 2008; Cuthbert 2010; Wittek and Kvernbekk 2011; Barrett 2011). Similarly, reviews of recent government policies have examined the way in which these policies have promoted particular marketised definitions of higher education (for example, see Brooks 2007; Boden and Nevada 2010; Collini 2011, 2012; Freedman 2011). This article adds to both these bodies of literature by focusing on the ways in which different definitions of quality are embedded in the documents of a range of organisations and agencies. In doing so, we seek to recognise that the government is only one of many actors, albeit a very important one, that seeks to shape what counts as 'quality' (Vidovich 2004) and to challenge the idea that understandings of what counts as high quality are simply imposed by government. Thus we seek to provide a more complex and comprehensive understanding of how dominant definitions of quality emerge across policy documents. In doing so, it is important to be clear that our focus is on definitions of quality embedded in policy documents rather than those embedded in the teaching and learning practices in higher education or the literature associated with these practices. Conceptualising definitions of quality through 'pedagogic discourse' In analysing policy documents, we were interested in how a how quality system of undergraduate education was positioned and whether particular definitions of quality appeared to be dominant across the documents and, if so, why. We conceptualised the concept of 'quality' using Bernstein's $(1990,2000)$ definition of pedagogic discourse, which is part of his wider concept of the pedagogic device (see Singh 2002; Ashwin 2009 for explanations of the pedagogic device). For Bernstein (1990, 2000), knowledge is central to an understanding of educational quality. He argues that the pedagogic discourse selects and recontextualises the knowledge that will be transmitted through formal education which influences the ways in which the identities of students are shaped by engaging with this knowledge. The production of pedagogic discourse is a struggle in which different actors seek to shape it. He identifies an Official Recontextualising Field (ORF) and Pedagogic Recontextualising Field (PRF) (Bernstein 2000; see also Singh, 2002; Marsh 2007; Beck 2009; Chen and Derewianka 2009), which he defines in the following terms: The recontextualising field always consists of an Official Recontextualising Field, created and dominated by the state for the construction and surveillance of state pedagogic discourse. There is usually (but not always) a Pedagogic Recontextualising Field consisting of trainers of teachers, writers of textbooks, curricular guides, etc., specialised media and their authors. Both fields may have a range of ideological pedagogic positions which struggle for control of the field. (Bernstein 2000, 115, emphasis in the original) There are two points that need to be made about this in relation to this article. First, as we are looking at definitions of quality in relation to policy documents, we are focused on the Official Recontextualising Field (ORF). As the above quote indicates, the ORF is dominated by the actors from the official field of the state and its 
regulatory bodies. Yet it also contains others who wish to have a voice in shaping the identities that are produced through pedagogic discourse. In relation to higher education, drawing on Clark's (1983) triangle of cooperation, this includes actors from the higher education field such as university, educational development, lecturer and student groups, and from the economic fields, such as business groups. As educational policies have increasingly been influenced by global organisations beyond the nation-state, it also includes actors from the international field, such as organisations focused on international cooperation (Marginson and Rhoades 2002; Vidovich 2004; Ball 2008; Blackmore 2009). Second, the role of the ORF is different in higher education than in school education because, as Bernstein (2000) recognises, universities have autonomy in setting their own curricula. Thus the struggle tends to be focused on the purposes and objectives of the higher education system as a whole (Blackmur 2007). The struggle over pedagogic discourse can be seen as defining quality in education in terms of the kinds of knowledge that students will have access to and the identities this produces. Bernstein (2000) examines three broad ways in which knowledge discourses can be recontextualised into pedagogic discourse. First, they can be recontextualised as singulars, in which disciplines maintain their unique voice, as they are 'insulated' from the discourses of other disciplines. Here definitions of quality are based around producing identities which have an inward commitment to pure knowledge (Bernstein 2000, 2001; Beck 2002; Beck and Young 2005). Second, where knowledge discourses are less insulated, Bernstein $(2000,9)$ argues that discourses are likely to be recontextualised as regions, which involves the recontextualisation of different singulars in relation to each other. Whereas singulars are pure disciplines that are only focused on defining the problems generated by their own discourses, regions are more focused on dealing with problems generated in the world outside of the discipline (Beck 2002). Here defi- nitions of quality are focused around producing identities where the commitment to knowledge is focused on its future use in the world, as in the case with the traditional professions such as Law and Medicine (Bernstein 2000, 2001; Beck 2002, 2009; Beck and Young 2005; Young 2008). Finally where the voice of the discipline is very weak, there are generic modes or 'genericism' (Beck and Young 2005) that are focused on developing 'trainability' in students, which is based on the idea that the world is in constant flux. Here definitions of quality are not focused around knowledge but rather the developing dispositions in students that will effectively equip them for the everchanging employment market (Bernstein 2000, 2001; Beck 2002, 2009; Beck and Young 2005; Jones and Moore 1995; Young 2008).

The research project

This policy analysis was undertaken as part of the Pedagogic Quality and Inequality Project, which was a three-year Economic and Social Research Council funded research project that focused on comparing the quality of teaching, learning and curricula in undergraduate sociology and allied subjects in four universities that have different reputations for the quality of the undergraduate experience that they offer. The study aimed to question the assumptions underlying these reputations through an in-depth exploration of the relations between what students bring to university, their experiences of university education and what they gain from it. We investigated what is taught, why and how; and how undergraduate students' and lecturers' experience and evaluate the curriculum and the teaching and learning environment. One aspect of the project was to investigate how policy debates appear to produce definitions of what counts as a highquality undergraduate education (a separate review of government policy documents on higher education is included in Abbas, Ashwin, and McLean 2012). 
Methodological approach

Selection of groups

In our analysis, we looked at policy documents from 32 actors that we organised into 11 groups. These groups were selected so that we included actors from the official, higher education, economic and international fields outlined above that can be seen as having an interest in the shape of higher education in England. The groups, actors and fields are outlined in Table 1. Whilst most of these categorisations were straightforward, it should be noted that we included in the Official Field government documents, governmentcommissioned independent reviews of higher education, reports from the UK parliament as well as the documents of regulatory agencies. The Quality Assurance Agency (QAA) was included in this latter group because, whilst it is officially an independent organisation, part of its funding is from government and it is largely seen as a regulatory body (for example, see the proposal in the Browne Report, Independent Review of Higher Education Funding and Student Finance [2010], that it be combined with the other regulatory bodies to form the Higher Education Council).

\section{Selection of documents}

We searched the websites of all of the actors and selected documents that were written as public statements of the actor's position in relation to higher education issues. In this way, we defined a policy document as a document that was intended to give an official account of that actor's views on higher education. This included annual and specially commissioned reports, evidence to parliamentary select committees, and responses to independent reports and government white papers. After an initial sorting of the documents, we decided to focus on documents that were published between the beginning of 2009 and the end of 2011. The reason for this was that the global economic crash of 2008 has been argued to have had a huge impact on public policy (Gamble 2010).

We wanted to examine documents that could be assumed to be written with awareness of this context rather than in relation to the policy situation prior to this event. Based on these selection criteria, we examined 133 documents.

Analysis of policy documents

In analysing the documents, we looked for statements that gave an insight into the actor's position on what counts as a high-quality undergraduate education. The initial selection was carried out by one researcher on the project whose selections were checked and added to by another project member, who then carried out some further searches and selections of documents. The selections were as inclusive as possible to include any statement that seemed to be based on a view of what a good undergraduate education is or should be. This part of the process resulted in extracts being taken from 91 of the 133 documents. These extracts were then imported into (NVivo 10) and codes assigned based on the particular aspect of a high-quality undergraduate education that was identified. In this stage of the analysis, 880 instances of accounts of a high-quality undergraduate education were identified under 80 different themes. These were grouped under four main headings: the characteristics of a high-quality undergraduate education system; what a high-quality 
undergraduate education system offers to students; the outcomes of a high-quality undergraduate education system; and how the quality of an undergraduate education system can be improved.

The approach to analysis was informed by arguments that policy can be analysed in order to understand how it positions the terms of particular debates (Ball 1994, 2008; Ozga 2000; Saarinen 2008; Saarinen and Ursin 2012). By examining documents from a wide range of organisations, which are likely to have different positions on what a highquality system of undergraduate education is or should be like, we were attempting to get a sense of the relations between the different positions on what counts as a highquality undergraduate education and to understand which appeared to be dominant and why. In order to judge the strength of support for particular conceptions of a good undergraduate education, we examined the number of times that these were expressed in the documents that we analysed.

In analysing the policy documents we deliberately did not draw on our theoretical framework. In Bernstein's (2000) terms, this was in order to create a 'discursive gap' between our theory and our data analysis so that the theory did not overly structure our outcomes (see Ashwin [2009, 2012] for a further discussion of this). We discuss the relationship between our outcomes and theoretical framework in the discussion section.

\section{Outcomes}

Following our approach to analysis, we present our outcomes in relation to the four headings outlined above and try to convey the different positions expressed in relation to each of these. These are illustrated with quotations from some of the policy documents, which were selected on the basis that they give a good illustration of the position that was suggested by a number of different groups of actors or because they expressed a view that was different from the others. The characteristics of a high-quality undergraduate education system The policy documents from business groups, the UK government, regulatory bodies, educational developers, international and student groups portrayed a high-quality system of undergraduate education as one in which there was a diversity of institutions and a flexible and diverse range of type of degree courses, with a range of modes of study that were responsive to the preferences of students. Thus they were not concerned with the range of disciplines that students could choose from but rather emphasised the flexibility of the system as whole to offer different structures of undergraduate programmes in a diverse range of institutional settings depending on the choices of students.

This position was nicely captured in the following quotations:

Better information will enable students to make informed choices about where to study. But that will not be enough unless popular higher education institutions and courses can expand, and new providers, including those who offer different models of higher education, can enter the market. (Department for Business Innovation and Skills 2011, 46)

The intention of the Coalition Government has been to create a marketplace, however it is essential that the Government fulfil their commitments to a market led sector by removing regulations which will otherwise impede development. The regulations on student numbers must be lifted, whilst maintaining an overall cap on student numbers greater flexibility should be introduced to allow providers to respond nimbly to the market. Flexibility in student numbers should be on the basis of 
demonstrable and consistent quality and demand for places rather than any arbitrarily imposed formula. (1994 Group 2011, paragraph 4.7)

The main divergence from this view came from the lecturer groups, who argued that without government funding to support a diversity of disciplines, institutions and kind of students, then student choice would be eroded. The need for government funding was also highlighted by university and student groups.

The essence of true choice in university is embodied in the diversity of subjects. It will be eroded by the proposals to allow narrowly-based new providers to cherry-pick courses, by the removal of public funding from the arts, humanities and social sciences, and by the proposals to reinforce the market position of 'selective universities', which will make them not simply more selective academically, but also more selective socially. Some institutions have a greater specialism in vocational subjects, others foster excellence in the natural sciences, medicine and technology, and others still specialise in the arts, performance and cultural analysis. What matters is that such diversity be properly funded so that each institution can provide the education appropriate to its context, and that each institution should be capable of developing in relation to that context. (Campaign for the Public University et al. 2011, 14)

Overall, under this heading, all of the groups highlighted the need for diversity and flexibility. The main disagreements were over whether student choice should drive the shape of the system, as suggested by actors from the official, economic, and international fields as well as some actors from the higher education field, or whether a diverse system should be maintained in order to offer a diverse range of students a full range of disciplines to choose from, which was suggested by some actors within the higher education field.

What a high-quality undergraduate education system offers to students There were two competing models of what a high-quality undergraduate education system offers to students. The first, which was reflected in the policy documents of the UK government, parliament, regulatory agencies, student groups, think tanks, university groups, and international organisations, emphasised that a high-quality undergraduate education system should provide students with up-to-date information and employability skills. This was not all that these groups emphasised but these two elements were heavily emphasised by all of these groups. The level of emphasis on up-to-date information and employability skills was nicely illustrated by the content and order of the first four overarching themes in the QAA's quality code, which sets out the definitive guide to the standards that higher education providers are required to meet:

Each Chapter of the Quality Code considers and addresses the following overarching themes ... . how information about the topic is communicated to students and other relevant audiences . how the employability of students can be addressed in relation to the topic . how equality and diversity issues have been embedded throughout . how the topic relates to all the diverse needs of students. (Quality Assurance Agency 2011, 9) 
Elements of an alternative to this model were expressed across the documents of lecturer, education developers, university and student groups. This model can be seen as emphasising the importance of a high-quality undergraduate education system offering students access to disciplinary knowledge, critical thinking, research skills and curricula that are shaped by students and researchers. However, this model was not expressed in full by any of these groups. For example, some aspects of this model were expressed in this extracts from a document written by representatives of the National Union of Students: If taken further though, a model of co-production also implies student involvement at the collective level. It suggests that institutions should bring students into the decisionmaking process, ask students to help design the curriculum, and give students control of some parts of the learning environment. (Streeting and Wise 2009, 3)

What was striking about this part of the analysis was the extent to which making information available to students and employability skills dominated the assertions of what a high-quality system of higher education offers to students. They were emphasised by groups from all of the fields and were by far the most common codes from the analysis as a whole. Whilst a different kind of model could be discerned across the documents of the groups from the higher education field, it was not clearly expressed and different aspects of this model were emphasised by different groups. The outcomes of a high-quality undergraduate education system The policy documents from the UK government, regulatory agency, university groups, educational developers and international groups emphasised the outcomes of meeting the needs of business, producing employable students and widening participation.

The importance of producing autonomous learners was emphasised more by university groups but this was very much in terms of preparing them for the employment market.

Research-led learning actively engages students in their learning experience, encouraging them to pursue new knowledge and to develop the independence of thought, critical thinking and entrepreneurial skills and ability to handle uncertainty and new problems - personal and professional skills that are integral to the graduate-level jobs that develop our knowledge economy. (Russell Group of Universities, undated, 1)

The international groups were alone in stressing that the outcomes of a high-quality system of undergraduate education be measured in terms of the knowledge and skills that students have gained by the time they graduate, through standardised testing.

However, this was part of an overall focus on producing employable students.

Lecturer groups emphasised the need to focus on broader social and cultural needs and those of local communities:

That vision is founded on a fundamental belief in the intrinsic value of education as a force for the enhancement of the lives of individuals, the liberation of their talents and the realisation of a truly civilised, socially responsible, fair and prosperous society. (University and College Union 2010, 1)

Under this heading the main disagreements were over the extent to which producing employable students should be the main outcome of the undergraduate education system. Again the actors in the higher education field appeared to be split on this whilst the actors from the official, economic, and international fields were more consistent. 
It was also striking that the documents from the student groups did not appear to contain statements about what the outcomes of a high-quality undergraduate system of education should be.

How the quality of undergraduate education system can be improved There were two competing models of how the quality of an undergraduate education system can be improved. There was a dominant model that could be characterised as a market version. This portrayed the quality of an undergraduate education system being developed through competition between institutions, student choice and making information public. These three elements are clearly linked, with the making of information public informing student choice and this leading to competition between institutions for students. This view was found in the policy documents of business groups, the UK government, independent reviews of higher education and higher education regulatory bodies. For example:

Rather than create a bureaucratic and imperfect measure for quality, our proposals rely on student choice to drive up the quality of higher education. Students need access to high quality information, advice and guidance in order to make the best choices. Improvements are needed. Providing students with clearer information about employment outcomes will close the gap between the skills taught by the higher education system and what employers need. (Independent Review of Higher Education Funding and Student Finance 2010, 28)

There was an alternative model that emphasised that the quality of undergraduate education would be improved by the development of teaching and student engagement in quality processes. Aspects of this model were emphasised by parliament, international organisations, developers, and student groups. For example:

We recommend that the Government in consultation with the higher education sector, including student representatives, draw-up and agree a strategy to require all university staff engaged in regular and significant teaching to undertake appropriate training in pedagogical skills and also to encourage staff across higher education institutions in England to obtain a professional teaching qualification. We further recommend that the Government require higher education institutions as a condition of support from the taxpayer to have in place programmes to enhance the teaching effectiveness of all academic staff who have teaching responsibilities. We recommend that, within its review processes, the QAA monitor and report on the extent to which institutions are demonstrably meeting this requirement. (Innovation, Universities, Science and Skills Committee 2009, 83-84)

Overall, there are two very contrasting models of how quality should be improved. One focused on improving quality through competition and another focused on improving quality through teaching development. There are three interesting aspects to this part of the analysis. First, unlike the other categories, there were divisions in the official field, with the government and parliament appearing to support different models for the improvement of quality. Interestingly, it is also the only time that the position of the international groups has differed from that of the government and groups from the economic field. However, it should still be emphasised that the market model of quality improvement was still dominant in the documents. Second, the university groups take a different view which emphasises their institutional autonomy but in doing so seem to end up endorsing the 
idea that quality should be improved through competition. Third, the policy documents from lecturer groups do not discuss how quality should be improved.

Discussion

From the analysis of the policy documents, it seems that the different actors in the ORF were engaged in a struggle over two competing pedagogic discourses that imply different kinds of identities for students and different relations to knowledge. The dominant discourse appeared to be a market-oriented generic discourse (Bernstein 2000, 2001; Beck 2002, 2009; Beck and Young 2005; Jones and Moore 2005; Young 2008) that is the focus of critiques of current higher education policies (Brooks 2007; Boden and Nevada 2010; Collini 2011, 2012; Freedman 2011). It positioned a high-quality undergraduate education system as one that is shaped by student choice; that provides students with clear information and employability skills; has the outcomes of meeting the needs of business, producing employable graduates and widening participation; and the quality of which is improved by student choice and competition between institutions.

It did not give a sense of the knowledge that students should gain access to as a result of engaging in undergraduate education but stressed the need for students to develop identities that are flexible and suited to the ever-changing employment market.

The alternative discourse, in the policy documents that we analysed, positioned a high-quality system of undergraduate education as one that actively maintains a diversity of students and disciplines; provides students with access to disciplinary knowledge, critical thinking, curricula that have been designed by students and academics, and teachers who are actively involved in scholarship and research; has the outcomes of widening participation, meeting students' wider social and cultural needs as well as the needs of local communities; and the quality of which is improved by teaching development and the engagement of students in quality processes. It is noteworthy that whilst moving away from a market-oriented discourse, this alternative did not give a sense of what is special about the knowledge that students are engaging with nor did it give a sense of the identities that they develop through this engagement. In the language of the literature on higher education quality (Harvey and Green 1993; Green 1994; Bowden and Marton 1998; Shields 1999; Morley 2003; Houston 2008; Cuthbert 2010; Wittek and Kvernbekk 2011; Barrett 2011), in the policy documents we analysed this discourse emphasised the transformation of students but it did not indicate how knowledge will transform them or what it will transform them into.

Compared to the dominant market discourse, the actors arguing the alternative model were much more fractured and less coherent. Whilst groups from the official and economic fields were fairly consistent in emphasising the dominant model in relation to all of the four aspects of a good undergraduate education that we examined, the four aspects of the alternative model were not clearly articulated by any of the actors we examined. Thus, whilst it is possible to imagine all the different actors in the higher education field coming together, particular actors aligned themselves with the market model in relation to different aspects of a high-quality undergraduate higher education system (as is the case with university and student groups) or did not articulate an alternative view in relation to some aspects (as is the case with lecturer groups in relation to improving quality). Thus, through this analysis, it can be seen that part of the reason that marketised definitions of quality dominated the policy documents was because the actors arguing for 
alternative definitions of quality were fractured, and the alternative definition was less coherently expressed through the documents.

There seem to be two reasons for this fracturing. First, as the ORF is dominated by the government, it is not surprising that those from the field of higher education are tempted to use the language of the government in order to establish the legitimacy of their claims (Dodds 2011) and to use this discourse when it matches their interests.

However, as different actors from the higher education field draw on different aspects of the dominant discourse, the overall effect is to reinforce rather to challenge or disrupt this discourse. Second, as was noted earlier, whilst the dominant market discourse was coherently focused on the market, the alternative discourse seemed to lack a unifying sense of the knowledge and identities that it is seeking to produce.

\section{Conclusion}

In conclusion, the implication of this research is that if the higher education field wants to more effectively challenge the dominance of the market-oriented generic discourse produced in the ORF, then it needs to unite around a more coherent and meaningful alternative. Drawing on Bernstein (2000), it seems that what is missing from the current alternative is a focus on the special relationships to particular kinds of academic knowledge, in both its singular and regional forms, that students gain through their undergraduate education and the identities that they will develop through engagement with these kinds of knowledge. In other words, the relations which students develop with particular kinds of academic knowledge through their undergraduate education and the impact this has on their identities needs to become central to definitions of what counts as a high-quality system of undergraduate education.

In emphasising the special relationships to particular kinds of academic knowledge that are generated through engagement in higher education, the higher education field can highlight the continuing importance of universities as critical and autonomous institutions that is threatened by the march of marketisation (Doherty 2011; Holmwood 2011; Molesworth, Scullion, and Nixon 2011; Collini 2012). Whilst Bok (2003) argues that universities can develop their own procedures to avoid the dangers of the empty language of marketisation, an alternative might be to focus discussions of the quality of undergraduate education around the relations that students develop to particular kinds of academic knowledge and the different identities these relations produce. This could be a way of bringing together a broader grouping of actors from the higher education field in order to contest the dominant marketised discourse of quality. Whether this is likely, given the ways in which the documents we examined tended to focus on the narrow interests of the particular actors in the higher education field, is a moot point. However, what our analysis makes clear is that the effect of the narrow focus of these actors is to reinforce a dominant pedagogic discourse that, in different ways, all of them are trying to challenge and disrupt.

\section{Acknowledgements}

This work was supported by the Economic and Social Research Council (Grant Number: RES- 062-231438). We acknowledge the work of Ourania Filippakou in undertaking the initial collection and selection of extracts from the policy documents. 


\section{References}

1994 Group. 2011. Submission to the future of higher education. http://www.publications.

parliament.uk/pa/cm201012/cmselect/cmbis/885/885we04.htm

Abbas, A., P. Ashwin. and M. McLean. 2012. Neoliberal policy, quality and inequality in undergraduate degrees. In Institutionalising neoliberalism in organisational formations: Theory, research and critical responses, ed. P. Whitehead and P. Crawshaw, 179-99. London: Anthem Press.

Ashwin, P. 2009. Analysing teaching-learning interactions in higher education: Accounting for structure and agency. London: Continuum.

Ashwin, P. 2012. How often are theories developed through empirical research in higher education?. Studies in Higher Education 37: 941-55.

Ball, S. 1994. Education reform: A critical and post-structuralist approach. Buckingham: Open University Press.

Ball, S. 2008. The education debate. Bristol: The Policy Press.

Barrett, R. 2011. On students as customers: Contesting the analogy. Higher Education Review 43, no. 2: 65-76.

Beck, J. 2002. The sacred and the profane in recent struggles to promote official pedagogic identities. British Journal of Sociology of Education 23: 617-26.

Beck, J. 2009. Appropriating professionalism: Restructuring the official knowledge base of England's 'modernised' teaching profession. British Journal of Sociology of Education 30: 3-14.

Beck, J., and M. Young. 2005. The assault on the professions and the restructuring of academic and professional identities: A Bernsteinian analysis. British Journal of Sociology of Education, 26: 183-97.

Bernstein, B. 1990. The structuring of pedagogic discourse: Volume IV. Class, codes and control. London: Routledge.

Bernstein, B. 2000. Pedagogy, symbolic control and identity: Theory, research and critique. Revised ed.. Oxford: Rowman \& Littlefield.

Bernstein, B. 2001. From pedagogies to knowledges. In Towards a sociology of pedagogy: The contribution of Basil Bernstein to research, ed. A. Morais, I. Neves, B. Davies, and H. Daniels, 363-68. New York: Peter Lang.

Blackmore, J. 2009. Academic pedagogies, quality logics and performative universities: Evaluating teaching and what students want. Studies in Higher Education 34: 857-72.

Blackmur, D. 2007. The public regulation of higher education qualities: Rationale, processes and outcomes. In Quality assurance in higher education: Trends in regulation, translation and transformation, ed. D. Westerheijden, B. Stensaker, and M. Rosa, 15-45. Dordrecht: Springer. 
Boden, R., and M. Nedeva. 2010. Employing discourse: Universities and graduate 'employability'. Journal of Education Policy 25: 37-54.

Bok, D. 2003. Universities in the marketplace: The commercialization of higher education. Princeton: Princeton University Press.

Bowden, J., and F. Marton. 1998. The university of learning: Beyond quality and competence in higher education. London: Kogan Page.

Brooks, R. 2007. Government rhetoric and student understandings: Discursive framings of higher education 'choice'. In Geographies of knowledge, geometries of power: Framing the future of higher education, ed. D. Epstein, R. Boden, R. Deem, F. Rizvi, and S. Wright, 232-47. New York: Psychology Press.

Brown, R. 2006. Higher education and the market: Protecting quality and diversity in a marketdriven system. Higher Education Review 39, no. 1: 3-15.

Brown, R. 2011a. A balanced higher education system. Higher Education Review 44, no. 1: 31-42.

Brown, R. 2011b. The coalition government's higher education reforms: Raising quality or nonsense on stilts? University of West London Professorial Lecture Series 2011-12, 14 December 2011.

Campaign for the Public University, Oxford University Campaign for Higher Education, Sussex

University Defends Higher Education, Warwick University Campaign for Higher Education, Humanities Matter, No Confidence Campaign, and Cambridge Academic Campaign for Higher Education. 2011. In defence of public higher education.

http://publicuniversity.org.uk/wpcontent/uploads/2011/09/In_Defence_of_Public_HE11.doc

Chen, H., and B. Derewianka. 2009. Binaries and beyond: A Bernsteinian perspective on change in literacy education. Research Papers in Education 24: 223-45.

Clark, B. 1983. The higher education system: Academic organisations in cross-national perspective. Berkeley, CA: University of California Press.

Collini, S. 2011. From Robbins to McKinsey. London Review of Books 33, no. 16: 9-14.

Collini, S. 2012. What are universities for? London: Penguin.

Cuthbert, R. 2010. Are students customers? Higher Education Review 42, no. 3: 3-25.

Department for Business, Innovation and Skills. 2011. Higher education: Students at the heart of the system. Cm8122. Norwich: The Stationery Office. http://discuss.bis.gov.uk/hereform/ white-paper/ Dill, D. 1997. Higher education markets and public policy. Higher Education Policy 10, no. 3/4: 16755.

Dill, D. 2007. Will markets assure academic quality? In Quality assurance in higher education: Trends in regulation, translation and transformation, ed. D. Westerheijden, B. Stensaker, and M. Rosa, 4772. Dordrecht: Springer. 
Dodds, A. 2011. The British higher education funding debate: The perils of 'talking economics'. London Review of Education 9: 317-31.

Doherty, T. 2011. For the university: Democracy and the future of the institution. London: Bloomsbury Academic.

Freedman, D. 2011. An introduction to education reform and resistance. In The assault on universities: A manifesto for resistance, ed. M. Bailey and D. Freedman, 1-11. London: Pluto Press.

Gamble, A. 2010. After the crash. Journal of Education Policy 25: 703-8.

Green, D., ed. 1994. What is quality in higher education? Buckingham: Society for Research into Higher Education and Open University Press.

Harvey, L., and D. Green. 1993. Defining quality. Assessment and Evaluation in Higher Education 18, no. 1: 9-34.

Holmwood, J., ed. 2011. A manifesto for the public university. London: Bloomsbury.

Houston, D. 2008. Rethinking quality and improvement in higher education. Quality Assurance in Education 16, no. 1: 61-79.

Innovation, Universities, Science and Skills Committee. 2009. Students and universities. London: The Stationery Office. http://www.publications.parliament.uk/pa/cm200809/ cmselect/cmdius/170/170i.pdf

Independent Review of Higher Education Funding and Student Finance (The Browne Report). 2010. Securing a sustainable future for higher education. http://www.bis.gov.uk/assets/ biscore/corporate/docs/s/10-1208-securing-sustainable-higher-education-browne-report Jones, L., and R. Moore 1995. Approaching competence: The competency movement in the New Right and the 'Culture Change' project. British Journal of Education and Work 2: 78-92.

Marginson, S., and G. Rhoades. 2002. Beyond national states, markets, and systems of higher education: A glonacal agency heuristic. Higher Education 43: 281-309.

Marsh, J. 2007. New literacies and old pedagogies: Recontextualizing rules and practices. International Journal of Inclusive Education 11: 267-281.

McCulloch, A. 2009. The student as co-producer: Learning from public administration about the student-university relationship. Studies in Higher Education 34: 171-83.

Meek, V.L., and F. Wood. 1997. The market as a new steering strategy for Australian higher education. Higher Education Policy 10, no. 3/4: 253-74.

Molesworth, M., R. Scullion, and E. Nixon, eds. 2011. The marketisation of higher education and student as consumer. Abingdon: Routledge.

Morley, L. 2003. Quality and power in higher education. Maidenhead: Society for Research into Higher Education and Open University Press. 
Ozga, J. 2000. Policy research in educational settings: Contested terrain. Buckingham: Open University Press.

Quality Assurance Agency. 2011. UK Quality Code for Higher Education: General introduction. Gloucester: Quality Assurance Agency. http://www.qaa.ac.uk/Publications/Information AndGuidance/Documents/Quality\%20Code\%20General\%20introduction\%20Dec11.pdf

Russell Group of Universities. undated. Research-led learning: the heart of a Russell Group university experience. http://www.russellgroup.ac.uk/uploads/Learning-in-a-research-intensi veenvironment.pdf

Saarinen, T. 2008. Position of text and discourse analysis in higher education policy research. Studies in Higher Education 33: 719-28.

Saarinen, T., and J. Ursin. 2012. Dominant and emerging approaches in the study of higher education policy change. Studies in Higher Education 37: 143-56.

Shields, P. 1999. Zen and the art of higher education maintenance: Bridging classic and romantic notions of quality. Journal of Higher Education Policy and Management 21, no. 2: 165-72.

Singh, P. 2002. Pedagogising knowledge: Bernstein's theory of the pedagogic device. British Journal of Sociology of Education 23: 571-82.

Streeting, W., and G. Wise. 2009. Rethinking the values of higher education - consumption, partnership, community? Gloucester: Quality Assurance Agency.

University and College Union. 2010. Education for the future: UCU's manifesto for post-school education. London: University and College Union. http://www.ucu.org.uk/media/pdf/e/r/ ucu_postschoolmanifesto_feb10.pdf

Vidovich, L. 2002. Quality assurance in Australian higher education: Globalisation and 'steering at a distance'. Higher Education 43: 391-408.

Vidovich, L. 2004. Global-national-local dynamics in policy processes: A case of 'quality' policy in higher education. British Journal of Sociology of Education 25: 341-54.

Watson, D. 2011. Cassandra and the politicians: Higher education and policy memory. Educational Review 634: 409-19.

Williams, G. 1997. The market route to mass higher education: British experience 1979-1996. Higher Education Policy 10, no. 3/4: 275-89.

Wittek, L., and T. Kvernbekk. 2011. On the problems of asking for a definition of quality in education. Scandinavian Journal of Educational Research 55: 671-84.

Young, M. 2008. Bringing knowledge back in: From social constructivism to social realism in the sociology of education. Abingdon: Routledge. 